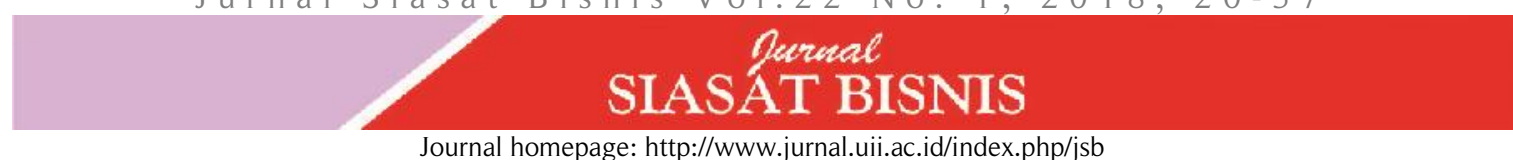

\title{
Identifikasi kompetensi manajerial pada level manajemen menengah dalam industri perbankan Indonesia
}

\author{
Jeni Wulandari ${ }^{1}$, Sam'un Jaja Raharja ${ }^{2}$, Herwan Abdul Muhyi ${ }^{2}$, Heru Nurasa ${ }^{2}$ \\ ${ }^{1}$ Kandidat Doktor Ilmu Administrasi Bisnis, \\ Program Pascasarjana Fakultas Ilmu Sosial dan Ilmu Politik, Universitas Padjadjaran, Bandung \\ Jln. Bukit Dago Utara 25, Bandung 40133, \\ *Corresponding Author: jeni.wulandari@unila.ac.id; jeni.wulandari@gmail.com
}

${ }^{2}$ Fakultas Ilmu Sosial dan Ilmu Politik, Universitas Padjadjaran Jln. Raya Bandung-Sumedang km 21 Jatinangor, Sumedang 45363

Received: 13-11-2017, Accepted: 21-02-2018, Published: 23-03-2018

\begin{abstract}
The purpose of this study is to identify managerial competencies at middle management level in Indonesian banking industry. The study was conducted by using sequential explanatory strategy on the mixed method approach. The results show that there are eight more dominant managerial competencies (often used and essential) for middle managers in banking sector, namely the competency of analytical thinking, developing others, impact and influence, team leadership, expertise/specialized knowledge, teamwork, achievement orientation, and conceptual thinking. However, there are three key competencies for middle managers in the banking sector that can affect the quality of their performance, namely the competency of developing others, impact and influence, and team leadership. The results of this identification can be used as a framework in developing competency models in Indonesian banking industry, and presents perspectives and methods that provide further support and expansion in competency studies.
\end{abstract}

Keywords: competency, identification, Indonesian bank, managerial competencies

\begin{abstract}
Abstrak
Tujuan dari studi ini adalah mengidentifikasi kompetensi manajerial pada level manajemen menengah dalam industri perbankan di Indonesia. Studi dilakukan dengan menggunakan strategi eksplanatoris sekuensial pada pendekatan mixed method. Hasil penelitian menunjukkan bahwa terdapat delapan kompetensi manajerial yang lebih dominan (sering digunakan dan esensial) bagi manajer menengah di bidang perbankan, yakni kompetensi berpikir analitis, mengembangkan orang lain, dampak dan pengaruh, kepemimpinan tim, pengetahuan spesifik, kerjasama tim, dorongan berprestasi, dan kompetensi berpikir konseptual. Walaupun demikian, ada tiga kompetensi kunci bagi manajer menengah di bidang perbankan yang dapat mempengaruhi kualitas kinerja mereka, yakni kompetensi mengembangkan orang lain, dampak dan pengaruh, serta kompetensi kepemimpinan tim. Hasil identifikasi ini dapat digunakan sebagai kerangka dalam mengembangkan model kompetensi dalam industri perbankan di Indonesia, dan menyajikan perspektif serta metode yang memberikan dukungan dan perluasan lebih lanjut dalam kajian kompetensi.
\end{abstract}

Keywords: kompetensi, identifikasi, perbankan Indonesia, kompetensi majerial

JEL: G2, J24, L84, M12, O15

DOI: 10.20885/jsb.vol22.iss1.art2

\section{Pendahuluan}

Identifikasi dan pengembangan kompetensi manajerial merupakan alat penting dalam manajemen sumber daya manusia untuk mencapai tujuan strategis organisasi. Kompetensi membantu sistem SDM untuk fokus pada pengembangan perilaku karyawan, dan kualitas kerja yang mendukung pada misi, nilai, dan tujuan strategis (Qadeer \& Hussain, 2016; Hijazeh, 2011; Sanghi, 2007; Dubois 
\& Rothwell, 2004). "Dinamika perkembangan dan perubahan saat ini pun, memberikan perhatian pada kepribadian dan kompetensi manajer sebagai sumber penting dalam mencapai keunggulan kompetitif" (Martina, Hana, \& Jiri, 2012).

Pada industri perbankan Indonesia khususnya, kompetensi manajerial menjadi aspek krusial yang harus dikembangkan untuk menghadapi ASEAN Banking Integrated Framework (ABIF) pada tahun 2020. Adanya ABIF membuat Indonesia tidak hanya kehadiran banyak bank asing yang akan berekspansi ke Indonesia, tapi adanya kesempatan dari bank-bank Indonesia yang selama ini susah berekspansi ke negara lain, untuk bisa membuka cabang dan mendapat perlakuan yang sama di negara lain (Syafina, 2015). Fenomena tersebut menjadi tantangan besar bagi perbankan Indonesia dalam menghadapi persaingan, tidak hanya dalam lingkup nasional, namun juga dalam skala regional dan global. Sementara untuk di Indonesia saja, kualitas pelayanan perbankan Indonesia masih belum terstandarisasi secara komprehensif, mulai dari kantor pusat, cabang-cabang utama dan cabang-cabang pembantu. Hal ini didukung pula dengan produktivitas SDM di bidang perbankan yang relatif stagnan (Otoritas Jasa Keuangan, 2014).

Selain itu, Indonesia juga dihadapkan dengan tantangan defisiensi manajer menengah, karena pada tahun 2020, Indonesia diperkirakan akan mengalami kesenjangan antara kebutuhan dan ketersediaan manajer menengah baik secara kualitas dan kuantitas sebesar 40 sampai 60 persen (Tong \& Waltermann, 2013, hal. 5). Sementara itu, manajer pada level manajemen menengah di bidang perbankan merupakan orang yang sangat berperan dalam menggerakkan sumber daya untuk mencapai target dan sasaran bisnis yang sudah ditetapkan pada level strategis. Manajer pada level ini merupakan eksekutor yang langsung berhubungan dengan konsumen dan pengalokasi sumber daya yang dimiliki perusahaan. Sehingga "manajemen menengah memiliki peran penting dalam menciptakan dan memelihara sistem manajemen yang efektif” (Drucker, 1980). Maka dengan itu, menjadi sesuatu yang krusial, khususnya bagi bank BUMN sebagai market leader perbankan Indonesia untuk mengidentifikasi dan mengembangkan kompetensi manajer di level tersebut dengan lebih sistematis, dalam upaya untuk menjamin posisi pasar dan memastikan pertumbuhan ekonomi dan keberhasilan dalam menghadapi persaingan global di masa mendatang (Handy, 1987, hal. 15).

Berdasarkan latar belakang tersebut, penelitian ini bertujuan untuk mengidentifikasi kompetensi manajerial pada level manajemen menengah dalam industri perbankan di Indonesia. Identifikasi kompetensi manajerial dilakukan dengan menggunakan pendekatan mixed method. Pendekatan mixed method digunakan karena penelitian ini merupakan riset berbasis kinerja, artinya hanya manajer dengan penilaian kinerja tertentu yang dapat dijadikan sampel dalam penelitian. Keterbatasan jumlah responden secara kuantitatif, perlu diuji dengan menggunakan pendekatan kualitatif untuk mendapatkan hasil yang lebih baik dalam mengidentifikasi kompetensi. Strategi yang digunakan dalam penelitian ini adalah strategi eksplanatoris sekuensial. Strategi ini diterapkan dengan pengumpulan dan analitis data kuantitatif pada tahap pertama yang diikuti oleh pengumpulan dan analisis data kualitatif pada tahap kedua, yang dibangun berdasarkan hasil awal kuantitatif. Rancangan ini digunakan untuk menjelaskan dan menginterpretasikan hasil-hasil kuantitatif berdasarkan hasil pengumpulan dan analisis data kualitatif (Creswell, 2013, hal. 316).

Terdapat beberapa penelitian terdahulu mengenai kompetensi manajerial (Balyer \& Özcan, 2017; Dziekoski, 2017; Szczepanska-Woszczyna \& Dacko-Pikiewicz, 2014; Chong, 2013; Saxena \& Bendale, 2013; Trivellas \& Drimoussis, 2013; Krajcoviva \& Cambal, 2012; Martina et al., 2012; Suh, West, \& Shin, 2012; Ras, 2011; Noor \& Dola, 2009; Capellen \& Janssens, 2008; Bakanauskienie \& Bartnikaite, 2006; Rajadhyaksha, 2005). Hal ini menunjukkan bahwa banyak studi telah dilakukan sebelumnya mengenai kompetensi manajerial. Walaupun demikian, tidak banyak pengukuran kompetensi yang berbasiskan penilaian kinerja superior. Analisis kerja tradisional dan pendekatan umum lainnya dalam mengidentifikasi kompetensi, memasukkan semua karyawan dalam pengumpulan data nya, sering tanpa membedakan antara data yang diperoleh dari karyawan yang berkinerja rendah, rata-rata, dan tinggi. Masalah bagi pendekatan tersebut bahwa karyawan yang 
berkinerja rendah dan rata-rata, mungkin tidak sepenuhnya memahami apa yang diperlukan untuk melakukan pekerjaan dengan luar biasa/superior (Marelli, Tondora, \& Hoge, 2005, hal. 543).

Identifikasi kompetensi manajerial juga banyak dilakukan dengan menggunakan satu teknik pengumpulan data, yang menyebabkan model kompetensi yang diidentifikasi menjadi kurang komprehensif dan akurat. Hal ini dikarenakan dalam mengidentifikasi kompetensi, setidaknya terdapat dua metode berbeda yang digunakan dalam pengumpulan data agar dapat saling melengkapi kelemahan dari penggunaan metode pengumpulan data secara tunggal (Marelli et al., 2005, hal. 544). Selain itu, tidak banyak pula penelitian yang memfokuskan kajian kompetensi manajerial pada level manajemen menengah. Studi mengenai manajemen menengah banyak memiliki kecenderungan umum terhadap pekerjaan atau peran manajemen menengah (Buss \& Kuyvenhofen, 2011; Kumarasinghe \& Hoshino, 2010; Huy, 2001; Brubakk \& Wilkinson, 1996; Mankidy, 1996; Singh \& Singh, 1994; Poval, 1985), tidak banyak studi yang melakukan identifikasi terhadap kompetensi manajer untuk dapat berkinerja efektif pada level tersebut.

Sehingga, berdasarkan perspektif studi dan kajian terdahulu, penelitian ini berupaya menyajikan suatu identifikasi kompetensi manajerial yang berfokus pada manajemen menengah dengan mengombinasikan pendekatan kuantitatif dan kualitatif (mixed method). Data dikumpulkan dengan menggunakan studi literatur, competency menu and database, survey berbasis kuesioner dan wawancara dengan manajer yang memiliki kinerja baik dan sangat baik di unit kerjanya. Output yang diharapkan dari penelitian ini berupa gambaran mengenai kompetensi manajerial secara umum pada manajer menengah bank BUMN di Indonesia untuk dapat berkinerja efektif, dilihat dari frekuensi penggunaan dan tingkat kepentingan kompetensi manajerial, serta mengetahui kompetensi manajerial kunci yang memiliki daya ungkit (leverage) pada level tersebut.

\section{Kajian Pustaka}

\section{Manajemen Sumber Daya Manusia Berbasis Kompetensi}

Manajemen SDM berbasis kompetensi merupakan suatu pendekatan pengelolaan orang dalam organisasi melalui kompetensi sebagai dasar dari keseluruhan fungsi manajemen SDM (Dubois \& Rothwell, 2004, hal. 36). Kompetensi dalam hal ini, membantu keputusan SDM yang berwawasan ke depan, dengan menjelaskan pengetahuan, keterampilan dan perilaku yang dibutuhkan di masa depan dan sebagai landasan untuk membangun proses seleksi, pelatihan, pengembangan profesional, penilaian kinerja dan perencanaan suksesi (Stone \& Bieber, 1997). Penggunaan kompetensi muncul karena memungkinkan sistem manajemen SDM untuk berkonsentrasi pada faktor yang berkontribusi secara langsung terhadap keberhasilan organisasi (Dubois \& Rothwell, 2004, hal. 36).

Kemunculan kompetensi secara ilmiah dikaji dalam literatur yang ditulis oleh White (1959) yang mengidentifikasi watak manusia sebagai kompetensi (Dubois \& Rothwell, 2004, hal. 17). McClelland (1973) lebih lanjut mengkristalisasikan konsep pengukuran kompetensi berdasar pada pengujian insiden kritis yang diasosiasikan dengan kinerja. Dalam artikelnya, McClelland mengemukakan bahwa uji terhadap sifat perilaku dan karakteristik lebih efektif daripada bakat dalam menentukan keberhasilan kinerja. Sifat dan karakteristik tersebut dapat menjadi pembeda antara yang berkinerja superior dan rata-rata (Itika, 2011, hal. 165).

Mirabile (1997) mendefinisikan kompetensi sebagai "sekumpulan pengetahuan (knowledge), keahlian (skills), dan kemampuan (abilities) yang saling berkaitan, dan atribut lainnya yang diasosiasikan dengan kinerja tinggi dalam suatu pekerjaan". "Ketika kompetensi yang dimiliki oleh manajer berkinerja tinggi menjadi kajian diskusi, istilah kompetensi manajerial menjadi sering digunakan" (Abraham, Karns, Shaw, \& Mena, 2001, hal. 842).

Kompetensi manajerial merupakan turunan dari nilai dan kompetensi inti organisasi (Abraham et al., 2001, hal. 842). Hal ini menunjukkan adanya alignment, yakni istilah yang digunakan untuk menggambarkan bagaimana kompetensi berkaitan dengan dimana organisasi akan berada nanti 
(tujuan strategis) dan talenta yang dibutuhkan untuk mencapainya (keahlian individu) (Hijazeh, 2011, hal. 28). Sehingga, terdapat hubungan yang erat antara kompetensi manajerial sebagai kompetensi individu dengan kompetensi organisasi (Wulandari, Raharja, Nurasa, \& Muhyi, 2017; Noerchoidah \& Eliyana, 2015; Martina et al., 2012; Memon, Mangi, \& Rohra, 2009; Abraham et al., 2001). Oleh karena itu, untuk membangun kompetensi organisasi sebagai suatu keunggulan kompetitif, tidak bisa lepas dari pengembangan kompetensi individu yang ada di dalamnya (Wulandari et al., 2017, hal. 39).

\section{Kompetensi Manajerial}

Kompetensi manajerial didefinisikan sebagai tipe spesifik dari kompetensi individu, yakni aktivitas, pengetahuan, keahlian atau sikap dan juga karakteristik personal yang diperlukan untuk memperbaiki kinerja manajemen (Martina et al., 2012, hal. 131). Boyatzis (1982, hal. 23) mendefinisikan kompetensi manajerial sebagai "karakteristik yang secara kausal berhubungan dengan kinerja yang efektif dan atau superior". Efektivitas kinerja adalah tercapainya hasil spesifik (outcomes) yang dipersyaratkan dalam pekerjaan melalui tindakan spesifik yang konsisten dengan kebijakan, prosedur, dan kondisi lingkungan organisasi (Boyatzis, 1982, hal. 12).

Kompetensi manajerial dapat disebut juga dengan kompetensi peran, karena kompetensi peran hanya relevan bagi karyawan yang memegang posisi manajerial. Kompetensi peran dikategorikan ke dalam kompetensi yang berhubungan dengan aktivitas, orang-orang, sumber daya, dan informasi. "Kompetensi peran berkontribusi pada model kompetensi ambil dan pakai (plug and play) karena tidak memiliki perbedaan yang signifikan dalam organisasi" (Palan, 2007, hal. 52). Pandangan tersebut sejalan dengan apa yang dikemukakan Spencer \& Spencer (1993) bahwa "kompetensi manajerial merupakan bagian khusus dari dampak dan pengaruh, mengekspresikan maksud untuk memiliki pengaruh spesifik tertentu". Maksud spesifik tersebut (untuk mengembangkan orang lain, memimpin orang lain, memperbaiki kerja tim dan kerjasama) merupakan hal yang penting khususnya bagi manajer (hal. 54). Hal ini yang kemudian dikembangkan lebih lanjut oleh Spencer \& Spencer (1993) dalam generic competency model for managers, karena kompetensi tersebut begitu umum di antara manajer. Kompetensi tersebut terdiri dari kompetensi dampak dan pengaruh, dorongan berprestasi, kerjasama, berpikir analitis, inisiatif, mengembangkan orang lain, percaya diri, memahami orang lain, pengarahan/ketegasan, pencarian informasi, kepemimpinan tim, berpikir konseptual, kesadaran berorganisasi dan membina hubungan, dan kompetensi pengetahuan spesifik.

Walaupun demikian, dalam perkembangannnya, kompetensi manajerial sebagai subjek dalam penelitian ilmiah telah menjadi pusat perdebatan. Kesepakatan pendapat pada aspek yang menentukan pada kompetensi manajerial belum pernah tercapai. Selain itu, tidak terdapat pula kesepakatan pendapat mengenai cara pengembangan kompetensi manajerial yang terbaik dan paling tepat (Bakanauskiene \& Bartnikaite, 2006, hal. 68). Tidak adanya kesepakatan tersebut dikarenakan konsep kompetensi tidak bersifat statis maupun universal, seperti yang langsung terkait dengan peran manajerial yang bersifat kontekstual. Dalam proses mengidentifikasi kerja manajer yang mencakup persyaratan dasar dan karakteristik manajerial, dipengaruhi oleh berbagai faktor seperti faktor lingkungan, pekerjaan, orang dan situasional (Mintzberg, 1973, hal. 103), sehingga diperlukan proses identifikasi kompetensi manajer yang sensitif terhadap konteks dan fungsi bisnis yang dijalankan.

Walaupun dalam mengidentifikasi kompetensi manajerial ini bersifat kontekstual, paling tidak dalam memahami kompetensi manajerial, terdapat empat pilar kompetensi, yakni memahami organisasi, memimpin dan mengelola orang, mengelola sumber daya, dan berkomunikasi secara efektif (Krajcovicova, Caganova, \& Cambal, 2012, hal. 1121). Berdasarkan keempat pilar kompetensi tersebut, kompetensi manajerial diklasifikasikan dalam tiga kelompok, yakni: Kompetensi manajerial umum, yakni kompetensi yang manajer seharusnya miliki, dapat memberikan kualitas kinerja dalam posisi manajemen; Kompetensi manajemen spesifik, yakni kompetensi yang dibutuhkan untuk memenuhi standar kinerja untuk posisi manajemen tertentu; dan kompetensi manajemen kunci, yakni 
kompetensi dimana manajer memberikan peningkatan terhadap pentingnya kompetensi tersebut, dan dapat meningkatkan kinerja karyawan (Krajcovicova et al., 2012, hal. 1120).

\section{Metode}

Penelitian ini menekankan pada identifikasi kompetensi manajerial umum dan mengetahui perbedaan kompetensi dilihat dari frekuensi penggunaan dan tingkat kepentingan kompetensi untuk menentukan kompetensi kunci dalam level manajemen menengah tersebut. Identifikasi kompetensi manajerial dilakukan dengan menggunakan kuesioner semi terbuka, berupa penilaian terhadap 14 kompetensi manajer yang terdapat dalam generic competency model of managers dari Spencer \& Spencer (1993) sebagai daftar rujukan penilaian kompetensi. Kompetensi kemudian diperingkat dengan melihat aggregate mean dari frekuensi penggunaan dan tingkat kepentingan kompetensi manajerial berdasarkan kondisi riil dalam menjalankan peran manajerial yang dilakukan. Responden memberikan penilaian dengan menggunakan skala likert yang terdiri dari pilihan 1) tidak pernah menggunakan, 2) jarang (0-30 persen waktu yang digunakan), 3) kadang-kadang (31-60 persen waktu yang digunakan), 4) sering (61-90 persen waktu yang digunakan), dan 5) selalu (91-100 persen waktu yang digunakan) dalam mengukur frekuensi penggunaan kompetensi dalam pekerjaan. Selain itu, responden juga memberikan peringkat terhadap tingkat kepentingan kompetensi dalam pekerjaan dengan pilihan 1) kurang penting, 2) penting, dan 3) sangat penting/esensial. Hasil penilaian 14 kompetensi manajerial tersebut menjadi gambaran awal kompetensi manajerial secara umum untuk dapat berkinerja efektif bagi manajer level menengah pada bank BUMN di Indonesia.

Teknik pengambilan sampel menggunakan purposive sampling dengan jumlah responden masing-masing kelompok sampel sedikitnya 20 subjek yang dipilih dari individu-individu yang memiliki pemahaman terhadap pertanyaan penelitian dengan baik dan memiliki penilaian kinerja yang baik dan sangat baik pada institusinya. Jumlah ini memungkinkan untuk dapat dilakukan pengujian hipotesis melalui uji tes statistik sederhana seperti t-test, chi-square, ANOVA, atau analisis fungsi diskriminan untuk mengetahui perbedaan rata-rata kompetensi yang ditunjukkan dalam berbagai level manajemen (Spencer \& Spencer, 1993, hal. 97). Oleh karena itu, sampel dalam penelitian ini ditentukan sebanyak 20 sampel manajer menengah dari dua bank BUMN di Indonesia yang memiliki performansi unggul dalam bisnis perbankan, baik pada lingkup domestik maupun internasional, yakni PT. Bank Rakyat Indonesia, Tbk. sebagai bank dengan laba terbesar di Indonesia selama dua belas tahun berturut-turut (Billy, 2017), dan PT. Bank Negara Indonesia, Tbk. sebagai bank dengan bisnis internasional terbaik se-Asia Tenggara (PT. Bank Negara Indonesia, Tbk., 2017). Total responden berjumlah 40 manajer menengah dari kedua bank BUMN tersebut. Namun, dari jumlah sampel penelitian yang diharapkan, hanya 27 responden yang memberikan umpan balik dalam kurun waktu tiga bulan penyebaran kuesioner. Hasil penilaian kompetensi manajerial tersebut lalu diuji dengan ANOVA untuk mengetahui perbedaan kompetensi manajerial berdasarkan frekuensi penggunaan dan tingkat kepentingan kompetensi dalam pekerjaan manajer.

Tahapan selanjutnya, data dianalisis dengan wawancara semi terstruktur pada enam orang manajer yang dipilih secara purposive berdasarkan hasil penilaian kinerja mereka yang baik dan sangat baik di institusinya, termasuk mereka yang sudah dipromosikan untuk naik jabatan pada level selanjutnya, dan mereka yang sangat menguasai penilaian kompetensi di institusinya. Informan ini terdiri dari satu orang Excecutive/Senior Vice President, tiga orang Vice President, dua orang Assistant Vice President. Data dianalisis melalui beberapa langkah: 1) Melakukan transkripsi wawancara, scanning materi, mengetik data lapangan, atau memilah-milah dan menyusun data ke dalam jenis-jenis yang berbeda tergantung pada sumber informasi; 2) Membangun general sense atas informasi yang diperoleh dan merefleksikan maknanya secara keseluruhan; 3) Menganalisis lebih detail dengan meng-coding data; 4) Menerapkan proses coding untuk mendeskripsikan setting, kategori-kategori, dan tema-tema yang akan dianalisis. Pengkategorian kompetensi hasil wawancara dipandu oleh kamus kompetensi 
generic competency model of managers (Spencer \& Spencer, 1993); 5) Menunjukkan deskripsi dan tema-tema ini dalam narasi/laporan kualitatif; 6) Menginterpretasi atau memaknai data dengan melakukan perbandingan antara hasil penelitian dengan informasi yang berasal dari literatur atau teori (Creswell, 2013, hal. 276). Secara umum, pemetaan kerangka kerja dalam mengidentifikasi kompetensi manajerial dalam penelitian ini dapat dilihat pada lampiran 2 .

\section{Hasil dan Pembahasan}

Berdasarkan hasil analisis kuantitatif, tabel 1 menunjukkan rata-rata keseluruhan penilaian responden terhadap tingkat kepentingan 14 kompetensi manajerial bagi pekerjaan manajer adalah sebesar 2,88. Artinya rata-rata responden menyatakan 14 kompetensi manajerial tersebut merupakan kompetensi yang esensial dibutuhkan dalam menjalankan peran manajerial. Tidak ada responden yang memberikan penilaian kurang penting atau kompetensi tersebut kurang dibutuhkan dalam pekerjaan manajer. Penilaian responden berkisar antara 2,67 hingga 3,00. Kompetensi memahami orang lain menjadi kompetensi yang mendapatkan penilaian terendah, sementara itu kompetensi dampak dan pengaruh menjadi kompetensi yang mendapatkan penilaian tertinggi sebagai kompetensi yang esensial dalam pekerjaan manajer level menengah di industri perbankan.

Sementara itu, dilihat dari frekuensi penggunaan 14 kompetensi manajerial menunjukkan rata-rata responden memberikan penilaian sebesar 4,18 atau dikategorikan sering menggunakan 14 kompetensi manajerial dalam pekerjaan mereka (sekitar 61-90 persen waktu yang digunakan dalam bekerja menggunakan kompetensi manajerial tersebut). Penilaian responden berkisar diantara 3,78 hingga 4,44, dengan kompetensi pencarian informasi berada pada penilaian kompetensi terendah dan kompetensi mengembangkan orang lain sebagai kompetensi yang mendapatkan penilaian tertinggi sering digunakan dalam pekerjaan manajer.

Tabel 1. Penilaian Tingkat Kepentingan dan Frekuensi Penggunaan 14 Kompetensi Manajerial

\begin{tabular}{|c|c|c|c|c|c|c|c|c|}
\hline \multirow[b]{2}{*}{ Kompetensi } & \multicolumn{3}{|c|}{ Tingkat Kepentingan } & \multicolumn{3}{|c|}{ Frekuensi Penggunaan } & \multirow{2}{*}{$\begin{array}{l}\text { Aggregate } \\
\text { Mean }\end{array}$} & \multirow{2}{*}{$\begin{array}{l}\text { Peringkat } \\
\text { Keseluruhan }\end{array}$} \\
\hline & Mean & $\begin{array}{l}\text { Std. } \\
\text { Dev }\end{array}$ & Peringkat & Mean & $\begin{array}{l}\text { Std. } \\
\text { Dev }\end{array}$ & Peringkat & & \\
\hline Dampak dan pengaruh & 3.00 & - & 1 & 4.26 & 0.59 & 5 & 7.26 & 3 \\
\hline Dorongan berprestasi & 2.81 & 0.40 & 10 & 4.26 & 0.45 & 6 & 7.07 & 7 \\
\hline Kerjasama tim & 2.93 & 0.27 & 5 & 4.26 & 0.53 & 7 & 7.19 & 6 \\
\hline Berpikir analitis & 2.96 & 0.19 & 2 & 4.33 & 0.55 & 3 & 7.30 & 1 \\
\hline Inisiatif & 2.89 & 0.32 & 7 & 4.07 & 0.68 & 9 & 6.96 & 9 \\
\hline Mengembangkan orang lain & 2.85 & 0.36 & 9 & 4.44 & 0.58 & 1 & 7.30 & 2 \\
\hline Percaya diri & 2.93 & 0.27 & 6 & 4.00 & 1.00 & 13 & 6.93 & 10 \\
\hline Memahami orang lain & 2.67 & 0.48 & 14 & 4.07 & 0.55 & 10 & 6.74 & 13 \\
\hline Pengarahan & 2.81 & 0.40 & 11 & 4.07 & 0.62 & 11 & 6.89 & 11 \\
\hline Pencarian informasi & 2.96 & 0.19 & 3 & 3.78 & 0.85 & 14 & 6.74 & 14 \\
\hline Kepemimpinan tim & 2.96 & 0.19 & 4 & 4.30 & 0.54 & 4 & 7.26 & 4 \\
\hline Berpikir konseptual & 2.89 & 0.32 & 8 & 4.15 & 0.60 & 8 & 7.04 & 8 \\
\hline $\begin{array}{l}\text { Kesadaran berorganisasi } \\
\text { dan membina hubungan }\end{array}$ & 2.78 & 0.42 & 13 & 4.07 & 0.78 & 12 & 6.85 & 12 \\
\hline Pengetahuan spesifik & 2.81 & 0.40 & 12 & 4.41 & 0.50 & 2 & 7.22 & 5 \\
\hline $\begin{array}{l}\text { Mean Penilaian } \\
\text { Keseluruhan }\end{array}$ & 2.88 & 0.30 & & 4.18 & 0.63 & & 7.05 & \\
\hline
\end{tabular}

Catatan: Pada jumlah rata-rata yang sama, kompetensi diperingkat mengikuti urutan kompetensi manajerial dari generic competency model of managers Spencer \& Spencer (1993) 
Apabila dilihat dari kedua aspek penilaian, baik dari tingkat kepentingan dan frekuensi penggunaan kompetensi dalam pekerjaan, terdapat delapan kompetensi manajerial yang dominan sebagai kompetensi esensial dan sering digunakan (penilaian rata-rata di atas 7), yakni kompetensi berpikir analitis, mengembangkan orang lain, dampak dan pengaruh, kepemimpinan tim, pengetahuan spesifik, kerjasama tim, dorongan berprestasi, dan kompetensi berpikir konseptual.

Selain itu, berdasarkan hasil uji ANOVA pada tingkat kepercayaan 95\%, menunjukkan signifikansi sebesar $0,259>\alpha 0,05$, dengan hasil $F$ hitung $(1,41)<F$ tabel $(4,24)$. Hal ini menunjukkan bahwa tidak terdapat perbedaan antara frekuensi penggunaan dan tingkat kepentingan kompetensi manajerial. Pada kedua aspek penilaian tersebut, manajer menengah memberikan penilaian yang sama pada kompetensi dampak dan pengaruh, berpikir analitis, dan kepemimpinan tim sebagai kompetensi yang sering digunakan dan esensial bagi pekerjaan mereka.

Selain 14 kompetensi manajerial dalam generic competency model of managers dari Spencer \& Spencer (1993), responden juga menambahkan kompetensi manajerial lain yang harus dimiliki oleh manajer level menengah dalam industri perbankan. Sebanyak 19 persen responden mengemukakan perlunya kompetensi orientasi pelayanan pelanggan, sebanyak 15 persen mengemukakan perlunya kompetensi integritas, 11 persen responden mengemukakan perlunya kompetensi kepedulian terhadap keakuratan, dan 4 persen responden mengemukakan perlunya kompetensi komunikasi dan profesionalisme.

Hasil analisis kuantitatif ini kemudian diperjelas dalam hasil wawancara semi terstruktur terhadap peran delapan kompetensi manajerial tersebut dalam pekerjaan manajer. Pertama, kompetensi berpikir analitis sebagai kompetensi yang mendapatkan penilaian tertinggi dilihat dari tingkat kepentingan dan frekuensi penggunaan. Kompetensi ini banyak berperan dalam proses penentuan keputusan kredit maupun penetapan sasaran bisnis bagi mereka yang bergerak di bidang bisnis. Bagi manajer yang bergerak di bidang support, kompetensi berpikir analitis berperan dalam keputusan penetapan kebijakan. Hal ini tergambar dalam rangkuman hasil wawancara pada tabel 2 berikut ini.

Tabel 2. Hasil Wawancara Kompetensi Berpikir Analitis

\begin{tabular}{cll}
\hline No & \multicolumn{1}{c}{ Rangkuman Wawancara } & Keterangan Informan \\
\hline 1. & $\begin{array}{l}\text { Manajer harus dapat mengidentifikasi kondisi wilayah dan internal } \\
\text { mereka yang berbeda-beda untuk menilai kelayakan debitur dan } \\
\text { mengelola sehat/tidaknya pinjaman. }\end{array}$ & I2, Vice President \\
2. $\begin{array}{l}\text { Manajer harus dapat menentukan potensi yang harus digali di } \\
\text { wilayah mereka untuk mencapai target yang sudah ditetapkan di } \\
\text { level strategis. }\end{array}$ & I3, Vice President \\
3. $\begin{array}{l}\text { Manajer harus dapat mengelola sumberdaya untuk menganalisis } \\
\text { kebutuhan kompetensi ke depan melalui pembedahan terhadap } \\
\text { proses bisnis yang ada. }\end{array}$ & $\begin{array}{l}\text { I6, Assistant Vice } \\
\text { President }\end{array}$ \\
$\begin{array}{l}\text { Manajer yang high potential (HiPo) dapat menganalisis setiap } \\
\text { permasalahan secara menyeluruh untuk mendapatkan kesimpulan } \\
\text { yang tepat sasaran dalam perbaikan kualitas layanan. }\end{array}$ & I1, Senior Vice President \\
\hline
\end{tabular}

Kedua, kompetensi mengembangkan orang lain merupakan kompetensi yang mendapatkan penilaian tertinggi sebagai kompetensi yang sering digunakan manajer menengah di bidang perbankan. Secara umum kompetensi ini menjadi penting untuk dimiliki oleh semua level manajerial. Karena manajer tidak hanya dituntut untuk mencapai target-target perusahaan, namun 
juga harus mampu membantu mengembangkan kemampuan anggota dan mendukung upaya pengembangan karir anggotanya. Hal ini dijelaskan dalam hasil wawancara berikut:

"Karena setiap pemimpin punya kewajiban untuk membikin pintar anak buahnya,

enggak pintar sendiri, untuk menyiapkan kader selanjutnya" (I4, Vice President).

Kompetensi ini ditunjukkan dalam bentuk mentoring, coaching, atau pemberian umpan balik yang bermanfaat untuk mengembangkan kemampuan anggotanya, termasuk dalam hal ini adalah memberikan kesempatan kepada anggotanya untuk menunjukkan potensi diri dalam rangka mendukung pengembangan karir jangka panjang anggota. Hal ini dijelaskan dalam rangkuman hasil wawancara pada tabel 3 berikut ini.

Tabel 3. Hasil Wawancara Kompetensi Mengembangkan Orang Lain

\begin{tabular}{clc}
\hline No & \multicolumn{1}{c}{ Rangkuman Wawancara } & \multicolumn{1}{c}{ Keterangan Informan } \\
\hline 1. & $\begin{array}{l}\text { Manajer memiliki tugas dan kewajiban untuk bisa } \\
\text { mengembangkan anak buahnya melalui pemberian feed back, } \\
\text { coaching serta mentoring yang dapat mempengaruhi hasil } \\
\text { assessment karir anak buahnya. }\end{array}$ & I6, Assistant Vice President \\
2. & $\begin{array}{l}\text { Manajer berperan dalam "memasarkan" potensi anggotanya } \\
\text { dengan memberikan kesempatan bagi anggota untuk } \\
\text { menunjukkan kemampuannya pada top management. }\end{array}$ & I3, Vice President \\
\hline
\end{tabular}

Ketiga, kompetensi dampak dan pengaruh merupakan kompetensi yang mendapatkan penilaian tertinggi sebagai kompetensi yang esensial bagi manajer level menengah di bidang perbankan. Pada level manajer menengah, terutama pada bidang bisnis seperti pimpinan cabang, kompetensi dampak dan pengaruh merupakan kompetensi yang sangat dibutuhkan. Karena pada level ini, manajer tidak hanya memiliki kemampuan untuk menggerakkan SDM yang dimilikinya agar dapat mengejar pencapaian target perusahaan, namun juga harus memiliki kemampuan dalam mempengaruhi pihak eksternal, terutama pada proses pemasaran produk perbankan di daerah yang menjadi cakupan wilayah kerjanya. Sebagaimana dalam rangkuman hasil wawancara pada tabel 4 berikut.

Tabel 4. Hasil Wawancara Kompetensi Dampak dan Pengaruh

\begin{tabular}{clc}
\hline No & \multicolumn{1}{c}{ Rangkuman Wawancara } & Keterangan Informan \\
\hline 1. & $\begin{array}{l}\text { Kapasitas kemampuan pemimpin cabang dalam menggerakkan orang } \\
\text { lain itu sangat penting. Kemampuan ini harus mendapat porsi yang lebih } \\
\text { tinggi. }\end{array}$ & I2, Vice President \\
2. & $\begin{array}{l}\text { Pemimpin cabang harus dapat memahami tipikal anak buah, karena } \\
\text { untuk menggerakkan orang harus memahami bagaimana cara }\end{array}$ & I2, Vice President \\
& mempengaruhi mereka untuk mau bergerak. \\
3. $\begin{array}{l}\text { Menjadi pimpinan cabang yang paling penting adalah mempengaruhi } \\
\text { orang lain, bukan hanya mempengaruhi calon nasabah, namun yang } \\
\text { paling mendasar adalah mempengaruhi orang-orang agar mau bekerja }\end{array}$ & I3, Vice President \\
sebaik-baiknya dengan kesadaran pribadinya. & \\
4. $\begin{array}{l}\text { Kemampuan menggerakkan orang secara bobot untuk di tingkat } \\
\text { eksekutor lebih ke bawah itu menjadi lebih tinggi, kompetensi } \\
\text { managerial skill seperti itu itu cukup dominan dalam level tersebut. }\end{array}$ & I5, Assistant Vice President \\
\hline
\end{tabular}

Keempat, kompetensi kepemimpinan tim, kompetensi ini bagi manajemen menengah dibutuhkan dalam proses monitoring, memastikan anggota bekerja sesuai standar yang diharapkan, 
termasuk meningkatkan efektivitas dalam pekerjaan. Selain itu, kompetensi ini juga tercakup dalam peran manajer yang merupakan contoh bagi anggotanya dan simbol perwakilan institusi di suatu daerah. Hal ini tergambar dalam rangkuman wawancara pada tabel 5 berikut ini.

Tabel 5. Hasil Wawancara Kompetensi Kepemimpinan Tim

\begin{tabular}{clc}
\hline No & \multicolumn{1}{c}{ Rangkuman Wawancara } & \multicolumn{1}{c}{ Keterangan Informan } \\
\hline 1. & $\begin{array}{l}\text { Pada level middle, mereka yang berkinerja bagus adalah orang } \\
\text { yang aktif melakukan monitoring, mengawal dan selalu } \\
\text { melakukan evaluasi secara rutin terhadap kinerja di bawah, } \\
\text { dan mampu untuk menggerakkan secara massif. }\end{array}$ & I2, Vice President \\
2. $\quad \begin{array}{l}\text { Pemimpin cabang harus memiliki kemampuan fleksibilitas } \\
\text { dalam menyelesaikan permasalahan yang dapat } \\
\text { mempengaruhi efektivitas pekerjaan. }\end{array}$ & I5, Assistant Vice President \\
3. $\begin{array}{l}\text { Pada level middle, mereka sudah memiliki anak buah yang } \\
\text { cukup banyak, sehingga mereka harus dapat menjadi contoh } \\
\text { yang baik. }\end{array}$ & I1, Senior Vice President \\
4. Pemimpin cabang harus dapat menerjemahkan perencanaan \\
$\begin{array}{l}\text { yang sudah ditetapkan dan efektifdalam mengeksekusi } \\
\text { perencanaan tersebut.Mereka adalah simbol dari kepala } \\
\text { kantor, menjadi wakil kantor yang ada di daerahnya. }\end{array}$ & I3, Vice President \\
\hline
\end{tabular}

Kelima, kompetensi pengetahuan spesifik merupakan kompetensi yang menjadi persyaratan dasar bagi seluruh manajer di bidang perbankan. Sebagaimana wawancara berikut ini.

"Hard kompetensinya juga harus dia miliki, kemampuan menganalisis kredit, bagaimana membuat neraca, menilai kelayakan suatu investasi, nah dia semuanya harus dimiliki juga, jadi tidak hanya sekedar soft kompetensinya saja, tapi hard kompetensinya juga harus dimiliki untuk bisa seseorang itu menjadi sukses" (I4, Vice President).

Kompetensi ini melekat dengan kompetensi berpikir analitis, terutama bagi manajer yang berada di bidang bisnis, kompetensi pengetahuan spesifik digunakan untuk menilai kelayakan pinjaman, pengambilan keputusan kredit, termasuk memahami layanan operasional perbankan. Sementara bagi manajer yang berada di bidang support, kompetensi pengetahuan spesifik begitu berperan dalam melakukan tugas fungsionalnya dalam menyusun suatu kebijakan tertentu, sehingga mereka sering disebut juga dengan technical leader. Hal ini tergambar dalam rangkuman wawancara pada tabel 6 berikut ini.

Tabel 6. Hasil Wawancara Kompetensi Pengetahuan Spesifik

\begin{tabular}{clc}
\hline No & \multicolumn{1}{c}{ Rangkuman Wawancara } & \multicolumn{1}{c}{ Keterangan Informan } \\
\hline 1. & $\begin{array}{l}\text { Secara teknis manajer menengah biasanya lebih lebih expert, mereka } \\
\text { dituntut harus tahu bagaimana cara menganalisis suatu kasus } \\
\text { tertentu, memastikan langkah-langkah yang dilakukan anak buahnya } \\
\text { sudah benar, sehingga skill knowledge yang paling kuat itu berada } \\
\text { di level middle manager. }\end{array}$ & I4, \\
2. $\begin{array}{l}\text { Secara teknis, penguasaan terhadap pengetahuan yang menjadi } \\
\text { bidang kerjanya adalah prasyarat utama, karena pimpinan menjadi } \\
\text { tempat bertanya dan dapat menilai kemampuan anak buah dalam } \\
\text { bekerja. }\end{array}$ & I5, Assistant Vice President \\
$\begin{array}{l}\text { Pada level middle, terutama kepala bagian, mereka adalah technical } \\
\text { leader. Jadi dia sudah memimpin, me-manage, menjalankan fungsi } \\
\text { manajerial, tapi dia masih tahu teknis. }\end{array}$ & I6, Assistant Vice President \\
\hline
\end{tabular}


Keenam, kompetensi kompetensi kerjasama tim. Kompetensi ini merupakan kompetensi yang dibutuhkan manajer untuk menguatkan hubungan pribadi dalam internal perusahan maupun menguatkan soliditas tim untuk bergerak dan bersinergi dalam satu kesatuan atau membangun semangat tim, termasuk menangani konflik yang terjadi dalam tim. Kompetensi ini juga merupakan salah satu kompetensi yang menjadi penilaian dalam pengembangan karir seorang manajer. Karena manajer yang dinilai baik tidak hanya diukur pada pencapaian target kerja, namun juga kemampuan mereka dalam membangun kerjasama yang baik dengan sesama rekan sejawat, atasan, maupun anggotanya. Sebagaimana rangkuman wawancara pada tabel 7 berikut.

Tabel 7. Hasil Wawancara Kompetensi Kerjasama Tim

\begin{tabular}{clc}
\hline No & \multicolumn{1}{c}{ Rangkuman Wawancara } & Keterangan Informan \\
\hline 1. & $\begin{array}{l}\text { Pemimpin tidak hanya orang yang bisa bekerja, namun mereka juga } \\
\text { mau bekerjasama. }\end{array}$ & I1, Senior Vice President \\
2. $\begin{array}{l}\text { Kompetensi managerial skill seperti itu cukup dominan di level } \\
\text { menengah, kemampuan menangani permasalahan SDM, menangani } \\
\text { konflik. }\end{array}$ & I3, Vice President \\
3. $\begin{array}{l}\text { Manajer berperan dalam menyatukan tim, membangun soliditas } \\
\text { dalam unit kerja yang luas sehingga dapat saling mengenal dan } \\
\text { dapat bekerja sama dengan baik. }\end{array}$ & I5, Assistant Vice President \\
4. $\begin{array}{l}\text { Mereka harus dapat membangun komunikasi yang lancar dalam } \\
\text { internal perusahaan, termasuk aktif bertanya pada rekan kerja terkait } \\
\text { dengan pengembangan bisnis dan pekerjaan mereka. }\end{array}$ & I2, Vice President \\
5. $\begin{array}{l}\text { Saat ini model arrangement-nya adalah mengajak bergerak bersama, } \\
\text { bekerja bersama, bukan sekedar helikopter view, namun ikut terlibat } \\
\text { dalam pekerjaan tersebut. }\end{array}$ & I2, Vice President \\
\hline
\end{tabular}

Ketujuh, kompetensi dorongan berprestasi. Secara umum, sebenarnya kompetensi ini merupakan salah satu kompetensi yang bersifat inti, artinya tidak hanya dimiliki pada level manajerial saja, namun juga pada setiap karyawan. Bagi manajer menengah, kompetensi ini dibutuhkan untuk menguatkan peran nya sebagai eksekutor dalam mencapai target laba yang sudah ditetapkan oleh perusahaan. Kinerja manajer dinilai dari angka pencapaian target. Oleh karena itu, angka pencapaian target menjadi ukuran keberhasilan dan prestasi manajer, semakin besar pencapaian yang dilakukan, maka semakin baik penilaian kinerjanya, dan itu mencerminkan tingginya prestasi manajer yang bersangkutan. Keaktifan manajer untuk terlibat dalam kegiatan perusahaan, kesediaannya dalam menerima tantangan, kemauan dalam mengembangkan kemampuan diri, termasuk di dalamnya mendorong keberhasilan tim juga menjadi indikator penilaian adanya kompetensi dorongan berprestasi. Sebagaimana terdapat dalam wawancara pada tabel 8 berikut ini.

Tabel 8. Hasil Wawancara Kompetensi Dorongan Berprestasi

\begin{tabular}{clc}
\hline No & \multicolumn{1}{c}{ Rangkuman Wawancara } & Keterangan Informan \\
\hline 1. & $\begin{array}{l}\text { Pembeda bagi mereka yang unggul dengan yang rata-rata terletak } \\
\text { pada militansinya terhadap pekerjaan, keinginan dia untuk melampaui } \\
\text { target kerja yang diharapkan. }\end{array}$ & I2, Vice President \\
2. $\begin{array}{l}\text { Kriteria bagi manajer yang high potential adalah mereka yang bekerja } \\
\text { dengan loyalitas, aktif untuk membantu dalam setiap kesempatan, } \\
\text { tidak memilih pekerjaan yang diberikan, termasuk bersedia menerima } \\
\text { tantangan dan memberikan lebih dari yang diharapkan. }\end{array}$ & I1, Senior Vice President \\
\hline
\end{tabular}


Delapan, kompetensi berpikir konseptual. Kompetensi ini banyak berperan dalam level menengah ke atas, terutama manajer yang bergerak di bidang support. Sebagaimana wawancara berikut.

"Semakin di atas, kompetensi soft nya yang akan semakin kuat, karena disitu dia harus mampu menjadi leader ya, leadership-nya yang harus kuat, berpikir strategisnya yang harus kuat, berpikir konseptualnya yang harus kuat" (I4, Vice President).

Kompetensi ini mencakup bagaimana melihat suatu pola atau kecenderungan terhadap situasi, menerapkan berbagai konsep/metode untuk menyelesaikan permasalahan dan dan menerapkan teori atau pemahaman masa lalu dalam menghadapi situasi. Hal ini tergambar dalam rangkuman wawancara pada tabel 9 berikut.

Tabel 9. Hasil Wawancara Kompetensi Berpikir Konseptual

\begin{tabular}{cll}
\hline No & \multicolumn{1}{c}{ Rangkuman Wawancara } & \multicolumn{1}{c}{ Keterangan Informan } \\
\hline 1. & $\begin{array}{l}\text { Dalam membawahi bagian assessment, tugasnya memikirkan } \\
\text { bagaimana assessment ini berjalan dengan baik dan bisa sesuai dengan } \\
\text { yang tentukan oleh perusahaan. }\end{array}$ & I4, Vice President \\
2. $\begin{array}{l}\text { Kepala bagian tugasnya lebih banyak pada berpikir konseptual, support } \\
\text { yang mendukung pada pelaksanaan eksekusi strategi di lapangan. }\end{array}$ & $\begin{array}{l}\text { I5, Assistant Vice } \\
\text { President }\end{array}$ \\
\hline
\end{tabular}

Berdasarkan hasil analisis kuantitatif di atas, dapat disimpulkan bahwa 14 kompetensi manajerial dari generic competency model of managers (Spencer \& Spencer, 1993) dapat menggambarkan kebutuhan kompetensi pada manajer bank di level manajemen menengah secara umum. Namun, terdapat delapan kompetensi manajerial yang lebih dominan (sering digunakan dan esensial) bagi manajer menengah di bidang perbankan, yakni kompetensi berpikir analitis, mengembangkan orang lain, dampak dan pengaruh, kepemimpinan tim, pengetahuan spesifik, kerjasama tim, dorongan berprestasi, dan kompetensi berpikir konseptual. Artinya, untuk dapat berkinerja efektif, manajer bank di level manajemen menengah minimal memiliki nilai assessment yang baik pada kedelapan kompetensi tersebut. Hal ini juga dikuatkan dengan hasil penelitian terdahulu yang memiliki substansi kompetensi kritis yang sama bagi keberhasilan manajer menengah, yakni kompetensi dalam membangun tim, komunikasi, koordinasi, eksekusi, dan pembelajaran yang berkelanjutan (continual learning) (Qiao \& Wang, 2009).

Kompetensi-kompetensi tersebut berperan bagi manajer menengah dalam menjalankan tugas sebagai penerjemah, perantara, penyangga, dan perunding. Tugas menerjemahkan mencakup mengomunikasikan dan menginterpretasikan perencanaan sehingga anggota dapat memahami tindakan apa yang harus diambil dan konteks tindakan tersebut. Tugas perantara memerlukan manajer menengah dalam menyelaraskan permintaan dan aktivitas yang berbeda-beda dari level strategis dan operasional dalam organisasi. Tugas menyangga memerlukan manajer menengah untuk mengurangi guncangan emosional dan dampak negatif tindakan orang lain melintasi batas antara manajemen senior dan level organisasi yang lebih rendah. Akhirnya, tingkat manajemen menengah bertindak sebagai perunding atau negosiator diantara berbagai level di organisasi (Balogun \& Hailey, 2008; Balogun, 2003).

Secara kuantitatif juga ditunjukkan bahwa kompetensi mengembangkan orang lain menjadi kompetensi yang sering digunakan pada level ini. Kompetensi ini digambarkan dengan seringnya menunjukkan harapan positif kepada bawahan, termasuk memberikan tugas yang dapat mengembangkan diri anggota, memberikan instruksi yang rinci, serta memberikan pengarahan dan contoh nyata untuk mempermudah bawahan melakukan pekerjaannya. Hal ini mendukung pada argumentasi bahwa "peran penting manajer saat ini adalah mendukung manajemen kinerja atau manajemen pembelajaran" (Salaman, 1995). Secara spesifik, saat ini terdapat pertukaran peran dari 
manajer sebagai pengendali menjadi manajer sebagai pelatih atau mentor, dimana mengembangkan karyawan sebagai bagian utama (Tamkin, Hirsh, \& Tyers, 2003). Sehingga, dalam banyak organisasi, mengembangkan bawahan dan membantu mereka untuk tumbuh dalam organisasi, esensial dipandang sebagai manajer yang berhasil (Slocum, Jackson, \& Hellriegel, 2010, hal. 12).

Kompetensi berpikir analitis juga mendapatkan penilaian tertinggi sebagai kompetensi yang sering digunakan dan esensial. Namun, tidak hanya bagi level manajemen menengah, kompetensi ini juga menjadi kompetensi yang penting bagi manajer yang berkinerja superior di berbagai level manajemen (Spencer \& Spencer, 1993, hal. 205). Kompetensi berpikir analitis mencakup kemampuan manajer dalam menganalisis situasi secara sistematis, menetapkan prioritas berdasarkan kepentingan dan merencanakan cara untuk mengantisipasi hambatan secara realistis, termasuk menganalisis apa yang dibutuhkan untuk menyelesaikan tugas atau mencapai tujuan.

Kompetensi dampak dan pengaruh juga menjadi kompetensi yang mendapatkan penilaian tertinggi sebagai kompetensi yang esensial di level tersebut. Hal ini juga didukung dengan hasil analisis kualitatif yang memberikan penekanan terhadap kompetensi dampak dan pengaruh dan kepemimpinan tim sebagai kompetensi yang dapat mempengaruhi kualitas kinerja manajer di level ini. Kompetensi dampak dan pengaruh merupakan kompetensi dengan bobot tertinggi sebagai kompetensi yang penting dimiliki oleh manajer yang superior dalam generic competency model of managers (Spencer \& Spencer, 1993, hal. 201). Kompetensi ini digambarkan dengan suatu kesan yang dapat menimbulkan dampak dan mempengaruhi seseorang untuk bertindak, baik melalui penggunaan data/informasi, menunjukkan contoh nyata atau pun manfaat dan alasan kepada orang lain dalam rangka memberikan pengaruh tertentu.

Kompetensi dampak dan pengaruh diperkuat dengan adanya kepemilikan kompetensi dorongan berprestasi yang tinggi, karena dorongan berprestasi menjadi elemen kompetensi yang melekat dengan motivasi need for power (termasuk sebagai bagian dari dampak dan pengaruh) (Spencer \& Spencer, 1993, hal. 203). Manajer dengan kompetensi ini digambarkan dengan seringnya mengukur keberhasilan pribadi maupun tim, bagaimana menetapkan cara bekerja yang lebih efisien, termasuk melakukan analisis untung rugi dalam mengambil keputusan yang berdampak baik untuk pribadi maupun tim. Walaupun demikian, kompetensi dorongan berprestasi lebih bersifat umum, artinya tidak hanya pada manajer level menengah, namun kompetensi ini menjadi pembeda manajer yang berkinerja superior dan rata-rata pada setiap level manajemen.

Sementara itu, pada kompetensi kepemimpinan tim, walaupun kompetensi ini tidak begitu signifikan menjadi pembeda antara manajer yang berkinerja superior dan rata-rata (Spencer \& Spencer, 1993, hal. 210), namun secara kuantitatif, responden memberikan penilaian kompetensi kepemimpinan tim sebagai kompetensi yang sering digunakan dan penting untuk dimiliki. Kompetensi ini dibutuhkan dalam proses monitoring, memastikan anggota bekerja sesuai standar yang diharapkan, termasuk meningkatkan efektivitas dalam pekerjaan. Standar kinerja dan efektivitas terutama di bidang perbankan, menjadi dasar dalam manajemen kinerja yang merupakan komponen penting dalam perbaikan berkelanjutan dan keberhasilan manajemen (Roghanian, Rasli, \& Gheysari, 2012; Acur \& Englyst, 2006; Neely, Gregory, \& Platts, 2005). Oleh karena itu, secara kualitatif, hasil penelitian juga menunjukkan kecenderungan kompetensi ini terhadap kualitas kinerja manajer menengah di bidang perbankan.

Berdasarkan hasil pembahasan tersebut, dapat disimpulkan bahwa terdapat delapan kompetensi umum bagi manajer menengah agar dapat berkinerja efektif, yakni kompetensi berpikir analitis, mengembangkan orang lain, dampak dan pengaruh, kepemimpinan tim, pengetahuan spesifik, kerjasama tim, dorongan berprestasi, dan kompetensi berpikir konseptual. Di samping itu, dari delapan kompetensi manajerial tersebut, ada tiga kompetensi kunci bagi manajer menengah di bidang perbankan yang dapat mempengaruhi kualitas kinerja mereka, yakni kompetensi mengembangkan orang lain, dampak dan pengaruh, serta kompetensi kepemimpinan tim. Apabila manajer menengah memberikan peningkatan terhadap pengelolaan ketiga kompetensi kunci ini 
dalam menjalankan peran manajerial mereka, hal ini dapat mempengaruhi keberhasilan kinerja manajer dan berdampak pada peningkatan kinerja karyawan (Krajcovicova et al., 2012, hal. 1120).

\section{Implikasi Teoritis dan Manajerial}

Secara teoritis hasil penelitian ini menunjukkan bahwa kompetensi manajerial tidak bersifat umum bagi setiap level manajemen (one for all). Untuk menjadi efektif, perbedaan posisi hirarki membutuhkan perbedaan perilaku manajerial (Qiao \& Wang, 2009, hal. 69). Terdapat beberapa logika yang menekankan perlunya berfokus pada kompetensi yang berbeda dalam tahap perkembangan yang berbeda (Zenger \& Folkman, 2014; Krajcovicova \& Cambal, 2012; Tap, Mohd, \& George, 2002; Boyatzis, 1982), karena fokus dan orientasi pada berbagai level manajemen mulai dari manajer lini, manajer menengah dan manajer puncak itu berbeda. Dengan demikian, penting untuk membagi kompetensi manajerial dalam berbagai tingkat dan kualitas (Krajcovicova \& Cambal, 2012, hal. 76). Selain itu, secara metodologis, untuk memperkuat validitas hasil identifikasi kompetensi, pendekatan mixed method dapat digunakan dalam menganalisis dan mengkaji kompetensi manajerial dengan lebih baik dibandingkan hanya menggunakan satu pendekatan.

Secara praktis, hasil penelitian berimplikasi terhadap pengembangan kompetensi manajerial pada manajer menengah di bidang perbankan di Indonesia. Karena pada dasarnya, kompetensi manajer perlu terus dilakukan penyesuaian agar relevan dengan perubahan strategi perusahaan mengikuti trend perubahan lingkungan bisnis di masa yang akan datang. Hasil identifikasi kompetensi manajerial ini dapat ditindaklanjuti dengan menyusun profil kompetensi dan mengembangkan kurikulum pelatihan yang tidak bersifat umum, dan disesuaikan dengan kebutuhan kompetensi manajer berdasarkan level manajerial mereka. Khususnya bagi manajer menengah saat ini, perlu nya pemahaman dan peningkatan keahlian/pengetahuan terhadap kompetensi dampak dan pengaruh, kepemimpinan tim, dan mengembangkan orang lain sebagai kompetensi kunci dalam posisi manajerial mereka. Manajemen juga harus memberikan prioritas terhadap kompetensi berpikir analitis, mengembangkan orang lain, dampak dan pengaruh, kepemimpinan tim, pengetahuan spesifik, kerjasama tim, dorongan berprestasi, dan kompetensi berpikir konseptual dalam memilih, mengembangkan, dan mengevaluasi calon manajer menengah potensial, agar dapat berkinerja efektif ketika manajer memasuki level manajemen tersebut.

\section{Simpulan}

Penelitian ini menyediakan gambaran mengenai kompetensi manajerial bagi manajer level menengah di bidang perbankan yang dapat digunakan sebagai kerangka dalam mengembangkan model kompetensi dalam industri perbankan di Indonesia. Hasil studi menunjukkan 14 kompetensi manajerial dari generic competency model of managers (Spencer \& Spencer, 1993) dapat menggambarkan kebutuhan kompetensi pada manajer bank di level manajemen menengah secara umum, dimana terdapat delapan kompetensi manajerial yang lebih dominan (sering digunakan dan esensial) bagi manajer menengah di bidang perbankan, yakni kompetensi berpikir analitis, mengembangkan orang lain, dampak dan pengaruh, kepemimpinan tim, pengetahuan spesifik, kerjasama tim, dorongan berprestasi, dan kompetensi berpikir konseptual. Walaupun demikian, ada tiga kompetensi kunci bagi manajer menengah di bidang perbankan yang dapat mempengaruhi kualitas kinerja mereka, yakni kompetensi mengembangkan orang lain, dampak dan pengaruh, serta kompetensi kepemimpinan tim.

Identifikasi kompetensi manajerial merupakan proses yang sensitif terhadap konteks, karena kompetensi manajerial bersifat tidak tetap dan seharusnya berhubungan dengan kebutuhan organisasi. Pengetahuan teknis dan konseptual terhadap fungsi dan bisnis yang dikelola adalah ambang batas yang diperlukan untuk kinerja yang wajar dalam mengelola fungsi tersebut. Perlu dilakukan studi lanjut untuk mengkaji penambahan kompetensi manajerial di luar generic 
competency model of managers, seperti kompetensi orientasi pelayanan pelanggan, integritas, kepedulian terhadap keakuratan, komunikasi dan kompetensi profesionalisme untuk menyesuaikan relevansi kebutuhan kompetensi manajerial dalam industri perbankan di masa yang akan datang.

\section{Referensi}

Abraham, S. E., Karns, L. A., Shaw, K., \& Mena, M. A. (2001). Managerial competencies and the managerial performance appraisal process. Journal of Management Development, 20(10), 842-852.

Acur, N., \& Engelyst, L. (2006). Assessment of strategy formulation: How to ensure quality in process and outcome. International Journal of Operations and Production Management, 26, 69-91.

Bakanauskiene, I., \& Bartnikaite, E. (2006). Managerial competence: The attitude of Lithuanian managers. Problems and Perspectives in Management, 4(2), 68-77.

Balogun, J. (2003). From blaming the middle to harnessing its potential: Creating change intermediaries. British Journal of Management, 14(1), 69-84.

Balogun, J., \& Hailey, V. H. (2008). Exploring strategic change. New Jersey: Prentice Hall.

Balyer, A. \& Özcan, K. (2017). Higher education administrators'managerial competency in Turkey. International Online Journal of Educational Sciences, 9(4), 917-929.

Billy, A. T. (2017). Aset Bank BRI tembuh batas hingga Rp. 1.003,6 triliun. Tribunnews.com. Diakses dari http://m.tribunnews.com/amp/bisnis/2017/02/01/aset-bank-bri-tembuh-batashingga-tp-1003-6-triliun.

Boyatzis, R. E. (1982). The competent manager: A model for effective performance. New York: Wiley.

Brubakk, B. \& Wilkinson, A. (1996). Agents of change? Bank branch managers and the management of corporate culture change. International Journal of Service Industry Management, 7(2), 21-43.

Buss, W. C., \&, Kuyvenhofen, R. (2011). Perceptions of European middle managers of their role in strategic change. Global Journal of Business Research, 5(5), 109-119.

Capellen, T., \& Janssens, M. (2008). Global managers career competencies. Career Development International, 13(6), 514-537.

Chong, E. (2013). Managerial competencies and career advancement: A comparative study of managers in two countries. Journal of Business Research, 66, 345-353.

Creswell, J. W. (2013). Research design. (A. Fawaid, Alih Bahasa). Yogyakarta: Pustaka Pelajar.

Drucker, P. (1980). Managing in turbulent times. Oxford: Butterworth-Heinemann Ltd.

Dubois, D. D., \& Rothwell, W. J. (2004). Competency-based human resource management. Mountain View, CA: Davies-Black Publishing.

Dziekoski, K. (2017). Project managers competency model for construction industry in Poland. Procedia Engineering, 182, 174-181.

Handy, C. (1987). The making of managers. London: MSC. 
Hijazeh, E. H. M. (2011). Adopting a competency based human resource management system in Palestine cellular communication LTD JAWWAL. Thesis, Faculty of Graduate Studies. Nablus, Palestine:, An-Najah National University.

Huy, Q. N., (2001). In praise of middle managers. Harvard Business Review, October, 72-79.

Itika, J. S. (2011). Fundamentals of human resource management: Emerging experiences from Africa. Leiden: African Studies Centre.

Krajcovicova, K., \& Cambal M. (2012). Typical managerial competencies of successful managers in industrial enterprises. Electronic International Interdisciplinary Conference,3-7 September, 74-76.

Krajcovicova, K., Caganova, D., \& Cambal, M. (2012). Key managerial competencies and competency models in industrial enterprises. Annals of DAAAM for 2012 \& Proceedings of the $23^{\text {rd }}$ International DAAAm Symposium, 23(1), 1119-1122.

Kumarasinghe, S., \& Hoshino, Y. (2010). The role and perceptions of middle managers and their influence on business performance: The case of Srilanka. International Business Research, 3(4), 3-16.

Mankidy, A. (1996). Woman managers in Indian bank. Sri Lankan Journal of Management, JulySeptember.

Marelli, A. F, Tondora, J., \& Hoge, M. A. (2005). Strategies for developing competency models. Administration and Policy in Mental Health, 32(5/6), 533-561.

Martina, K., Hana, U., \& Jiri, F. (2012). Identification of managerial competencies in knowledgebased organizations. Journal of Competitiveness, 4(1), 129-142.

McClelland, D. (1973). Testing for competence than for 'intelligence'. American Psychologist, 28(1), 1-14.

Memon, M. A., Mangi, R. A., \& Rohra, C. L. (2009). Human capital a source of competitive advantage "ideas for strategic leadership. Australian Journal of Basic and Applied Sciences, 3(4), 4182-4189.

Mintzberg, H. (1973). The nature of managerial work. NY: Harper \& Row Publisher.

Mirabile, R. J. (1997). Everything you wanted to know about competency modeling. Training and Development, 51, 73-77.

Neely, A., Gregory, M., \& Platts, K. (2005). Performance measurement system design: A literature review and research agenda. International Journal of Operations and Production Management, 25, 1228-1263.

Noerchoidah, \& Eliyana, A. (2015). The study between competence and human capital: Towards a competitive advantage. IOSR Journal of Business and Management, 17(2), 4-17.

Noor, K. B. M., \& Dola, K. (2009). Job competencies for Malaysian managers in higher education institution. Asian Journal of Management and Humanity Sciences, 4(4), 226-240.

Otoritas Jasa Keuangan. (2014, Desember). Peran lembaga sertifikasi dalam mendorong perbankan yang berdaya saing menghadapi MEA. Diakses dari http://lspp.or.id/wpcontent/uploads/2014/12/Peran-Sertifikasi-Perbankan.pptx\&ved.

Palan, R. (2007). Competency management. (O. M. Jalal, Alih Bahasa). Jakarta: Penerbit PPM. 
Poval, M. (1985). Women in banking. In B. L. Livy (Ed.), Management and people in banking (pp. 325-340). London: The Chartered Institute of Bankers.

PT. Bank Negara Indonesia, Tbk. (2017). BNI miliki divisi internasional terbaik layanan trade finance BNI tetap terunggul. Diakses dari www.bni.co.id/id-id/beranda/berita/siaranpers/articleid/3358.

Qadeer, F., \& Hussain, S. (2016). Antecedents of transition toward strategic HRM in developing countries. Asian Management Research Journal, 1 (1), 4-21.

Qiao, J. X., \& Wang, W. (2009). Managerial competencies for middle managers: Some empirical findings from China. Journal of European Industrial Training, 33(1), 69-80.

Rajadhyaksha, U. (2005). Managerial competence: Do technical capabilities matter?. Vikalpa, 30(2), 47-56.

Ras, G. J. M. (2011). Exploring global competence with managers in India, Japan, and the Netherlands: A qualitative Study. University of Nebraska: Educational Administration Departement.

Roghanian, P., Rasli, A., \& Gheysari, H. (2012). Productivity through effectiveness and efficiency in the banking industry. The 2012 International Conference on Asia Pacific Business Innovation and Technology Management, Social and Behavioral Sciences, Proceeding, 40, 550-556.

Salaman, G. (1995). Managing. Maidenhead, UK: Open University Press.

Sanghi, S. (2007). The handbook of competency mapping. New Delhi: Sage Publications India Pvt. Ltd.

Saxena, P., \& Bendale, S. (2013). Managerial competencies in Indian business context: An empirical analysis. Singaporean Journal of Business Economics and Management Studies, 2(1), 101109.

Singh, A. K., \& Singh, R. (1994). Effective executive behaviour among middle managers. South Asian Journal of Management, July-September.

Slocum, J. W., Jackson, S. E., \& Hellriegel, D. (2010). Competency-based management. USA: South-Western Cengage Learning.

Spencer, L. M., \& Spencer, S. M. (1993). Competence at work: Models for superior performance. USA: John Wiley \& Sons, Inc.

Stone, B. B., \& Bieber, S. (1997). Competencies: A new language for our work. Journal of Extension, 35(1). https://www.joe.org/joe/1997february/comm1.php.

Suh, E., West, J. J., \& Shin, J. (2012). Important competency requirements for managers in the hospitality industry. Journal of Hospitality, Leisure, Sport \& Tourism Education, 11(2), 101-112.

Syafina, D. C. (2014). OJK dan Bank Sentral Malaysia Sepakati ABIF. Kontan Mobile. Diakses dari http://mobile.kontan.co.id/news/2015-ojk-dan-bank-sentral-malaysia-sepakati-abif.

Szczepanska-Woszczyna, K., \& Dacko-Pikiewicz, Z. (2014). Managerial competencies and innovations in the company: The case of enterprises in Poland. Business, Management and Education, 12(2), 266-282.

Tamkin, P., Hirsh, W., \& Tyers, C. (2003). Chore to champions: The making of better people managers. IES Report 389. UK: The Institute for Employment Studies. 
Tap, B., Mohd, S., \& George, T. (2002). Training needs assessment: Report on the public service of Samoa. London, UK: United Kingdom.

Tong, D., \& Waltermann, B. (2013). Growing pains, lasting advantage: Tackling Indonesia's talent challenges. The Boston Consulting Group.

Trivellas, P., \& Drimoussis, Ch. (2013). Investigating leadership styles, behavioural and managerial competency profiles of successful project managers in Greece. Procedia-Social and Behavioural Sciences, 73, 692-700.

White, R. (1959). Motivation reconsidered: The concept of competence. Psychological Review, 66, 279-333.

Wulandari, J., Raharja, S. J., Nurasa, H., \& Muhyi, H. A. (2017). Individual competency study in the evolution of human resource management theory and its relation to organizational competency. International Journal of Management and Administrative Sciences, 5(03), 3543.

Zenger, J., \& Folkman, J. (2014). The skills leaders need at every level, Harvard Business Review, July. Diakses dari https://hbr.org/2014/07/the-skills-leaders-need-at-every-level. 


\section{Lampiran}

1. A Generic Competency Model of Managers

\begin{tabular}{crl}
\hline No & Weight & \multicolumn{1}{c}{ Competency } \\
\hline 1. & $\mathrm{XXXXXX}$ & Impact and Influence \\
2. & $\mathrm{XXXXXX}$ & Achievement Orientation \\
3. & $\mathrm{XXXX}$ & Teamwork and Cooperation \\
4. & $\mathrm{XXXX}$ & Analytical Thinking \\
5. & $\mathrm{XXXX}$ & Initiative \\
6. & $\mathrm{XXX}$ & Developing Others \\
7. & $\mathrm{XX}$ & Self-Confidence \\
8. & $\mathrm{XX}$ & Interpersonal Understanding \\
9. & $\mathrm{XX}$ & Directiveness/Assertiveness \\
10. & $\mathrm{XX}$ & Information Seeking \\
11. & $\mathrm{XX}$ & Team Leadership \\
12. & $\mathrm{XX}$ & Conceptual Thinking \\
13. & Base Requirements & (Organizational Awareness and Relationship Building) \\
14. & & Expertise/Specialized Knowledge \\
\hline
\end{tabular}

Sumber: Spencer \& Spencer (1993:201)

\section{Kerangka Kerja Identifikasi Kompetensi Manajerial}

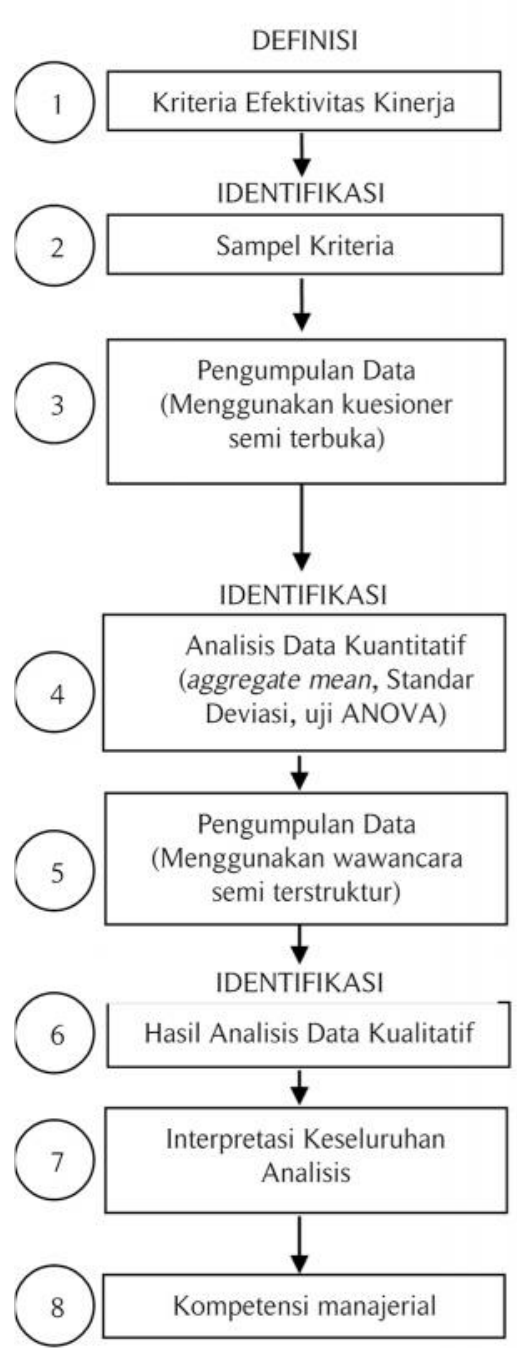

Analisis data sekunder: profil perusahaan, job description, Key Performance Indicator, competency menu and database, hasil penilaian kinerja. Output berupa gambaran kompetensi manajerial yang dibutuhkan.

Identifikasi sampel kriteria manajer pada level manajemen menengah pada dua bank BUMN, yakni PT. BRI, Tbk., dan PT. BNI, Tbk. Adapun kriteria sampel merupakan manajer yang mendapatkan penilaian kinerja baik dan sangat baik berdasarkan hasil pengukuran kinerja di institusinya.

Teknik pengambilan sampel menggunakan purposive sampling. dengan jumlah responden masing-masing kelompok sampel sedikitnya 20 subjek. Jumlah ini memungkinkan untuk dapat dilakukan pengujian hipotesis melalui uji tes statistik sederhana untuk mengetahui perbedaan rata-rata kompetensi yang ditunjukkan dalam berbagai level manajemen (Spencer \& Spencer, 1993:97).

Identifikasi kompetensi manajerial dilakukan pada sampel kelompok manajer pertama secara kuantitatif.

Wawancara pada enam orang manajer yang dipilih secara purposive berdasarkan hasil penilaian kinerja/prestasi, dan kedalaman pengetahuan mengenai penilaian kompetensi di institusinya.

Identifikasi kompetensi manajerial berdasarkan hasil wawancara informan.

Proses pencampuran (mixing) data kuantitatif dan kualitatif serta studi literatur. Proses interpretasi kompetensi manajerial dibantu dengan menggunakan kamus kompetensi generic competency model of managers (Spencer \& Spencer, 1993).

Kompetensi manajerial secara umum dan kompetensi kunci pada manajer menengah di bidang perbankan. 